\author{
레이저 직접적층법으로 제조된 $\mathrm{Fe}-8 \mathrm{Cr}-3 \mathrm{~V}-2 \mathrm{Mo}-2 \mathrm{~W}$ 합금의 \\ 마모특성에 미치는 열처리공정 및 상대재의 영향

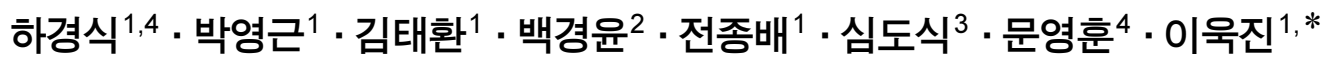 \\ 1한국생산기술연구원 동남본부 \\ 2한국생산기술연구원 서남본부 \\ 3 한국해양대학교 기계공학부 \\ ${ }^{4}$ 부산대학교 기계공학부
}

\title{
Effects of Heat Treatment Condition and Counter Materials on the Wear Behavior of Laser Direct Energy Deposited Fe-8Cr-3V-2Mo-2W Alloy
}

\author{
Kyeongsik Ha ${ }^{1,4}$, Young Keun Park ${ }^{1}$, Taehwan Kim ${ }^{1}$, Gyeong Yun Baek ${ }^{2}$, \\ Jong Bae Jeon', Do-sik Shim³, Young Hoon Moon', and Wookjin Lee',* \\ ${ }^{1}$ Dongnam Division, Korea Institute of Industrial Technology, Yangsan 50623, Republic of Korea \\ ${ }^{2}$ Seonam Division, Korea Institute of Industrial Technology, Gwangju 61007, Republic of Korea \\ ${ }^{3}$ Division of Mechanical Engineering, Korea Maritime and Ocean University, Busan 49112, Republic of Korea \\ ${ }^{4}$ Department of Mechanical Engineering, Pusan National University, Busan 46241, Republic of Korea
}

\begin{abstract}
This study aimed to investigate the wear performance of laser direct energy deposited Fe-8Cr$3 \mathrm{~V}-2 \mathrm{Mo}-2 \mathrm{~W}$ alloy under various wear environments, in terms of different heat treatment conditions. Ball on disk tribology tests were performed using high-carbon steel and zirconia balls as counter materials. The wear rates of the alloy depended significantly on both the wear sliding speed and the wear load. Microstructural observations of the worn surface and the wear debris indicated intensive tribo-oxidative wear that was presumably responsible for the strong dependency of the wear rate on the wear sliding speed. Regardless of the type of counter materials, the alloy in the as-built state had better wear performance than the alloy with heat treatments. Therefore, the use of the alloy without post heat treatment would be favorable to obtain long-term durability of the alloy in severe wear environments. The wear tests with two different counter materials of high-carbon steel and zirconia showed the highcarbon steel counter material had a higher wear rate than the zirconia. This was thought to be due to that strong third-body abrasive actions of the high-carbon steel counter material, evidenced by the severe abrasive wear of the counter material.
\end{abstract}

(Received May 20, 2020; Accepted August 19, 2020)

Keywords: direct energy deposition, ball on disk, metal additive manufacturing, high-wear resistance steel, wear, heat treatment

\section{1. 서 론}

레이저 직접 적층 공정 (direct energy deposition, $\mathrm{DED})$ 은 분말 또는 와이어 형태의 금속 원 소재를 고출

\footnotetext{
- 하경식·박영근: 박사과정, 김태환·전종배·이욱진: 연구원, 백경윤·심도식·문영훈 : 교수

*Corresponding Author: Wookjin Lee

[Tel: +82-51-510-3967, E-mail: wkjinlee@kitech.re.kr]

Copyright (C) The Korean Institute of Metals and Materials
}

력 레이저와 같은 높은 에너지를 가진 열원을 통해 용융하 여 3차원의 물체를 쌓는 방식으로 금속소재를 사용자가 원 하는 형상으로 적층 하는 공정이다. 반복적으로 높은 에너 지를 직접 투입해서 용융풀을 형성시키며 적층하기 때문에, 기공이 거의 없는 높은 성형밀도의 조형물을 얻기 쉽고 선 택적 레이저 적층 등 타 적층공정에 비하여 빠른 적층속도 를 가지는 공정 특성을 가지고 있다 [1-3]. 그리고 공정 특성상 적층할 대상모재의 형상에 대한 별다른 제약이 없 고, 원하는 부분을 선택하여 국부적인 적층이 가능한 이점 
을 가지고 있다. 이런 다양한 장점 때문에 $\mathrm{DED}$ 공정은 향후 대형 기어부품이나 금형 등의 기계부품의 보수 및 국 부강화, 하드페이싱 등에 적용이 기대되고 있다 [4-10].

Fe-8Cr-3V-2Mo-2W (wt\%) 합금은 Rovalma S.A. (Barcelona, Spain) 사에서 소결용 합금분말로high wearresistance steel (HWS) 이라는 제품명으로 상용화 한 고 내마모성 특수합금강이다. HWS는 소결시 내부에 미세한 금속간화합물과 탄화물이 형성되어 높은 경도와 매우 우수 한 내마모성을 보이는 특징을 가지고 있으며, 소결을 통해 높은 내마모성을 요구하는 펀치 인서트 팁 등의 금형이나 공작기계의 공구 등으로 활용되고 있다 [7,8,11]. 한편, 최 근 본 저자들은 소결용 상용 $\mathrm{HWS}$ 분말과DED 공정을 응 용하여 결함이 거의 없는 HWS 하드페이싱 층을 $5 \mathrm{~mm}$ 이상 성공적으로 적층하였으며, 적층된 합금의 미세조직과 기계적 특성을 분석하였다 [12]. DED로 적층된 HWS 합 금은 기존에 냉간금형강으로 널리 사용되는 AISI D2 소재 에 비해 높은 표면경도와 매우 우수한 마모특성을 보였으 며, 충격인성 역시 as-built 상태에서 AISI D2 소재에 비 해 매우 높았다. 따라서 $\mathrm{HWS}$ 합금은 향후 $\mathrm{DED}$ 를 통해 금형이나 대형 기어부품의 보수, 국부강화 및 하드페이싱 등 지속적인 마찰이 발생하여 높은 내마모성이 필수적인 기계구조물에 적용이 매우 유망한 소재로 사료된다.

$\mathrm{DED}$ 공정을 금형이나 기어부품 등에 적용하기 위해서 는 기계부품에 가해지는 충격을 견딜 수 있는 소재를 결 함 없이 적층할 수 있는 $\mathrm{DED}$ 공정에 대한 연구와 함께, 실제로 기계부품에서 재료에 반복적으로 가해지는 마찰과 마모조건 하에서의 상세한 재료거동에 대한 분석이 병행 되어야 한다 [13]. DED 공정으로 제조된 합금의 미세조 직은 레이저를 통한 매우 빠른 용융과 응고로 형성된 비 드가 서로 겹쳐져 있는 복잡한 구조를 가지고 있으며, 일 반적으로 $\mathrm{DED}$ 공정으로 제조한 합금은 공정 중 급속한 냉각 때문에 기존의 주조, 압연, 단조 등 전통적인 금속 제조공정으로 만든 합금과 비교하여 미세한 결정립 구조 를 가지고, 이 때문에 높은 기계적 특성을 보이는 것으로 알려져 있다 $[14,15] . \mathrm{DED}$ 공정으로 제조한 고경도 철 계 합금의 마모특성을 전통적인 제조공정으로 만든 동일 합금과 비교한 결과는 아직 논문에서 제시된 바는 없으 나, $\mathrm{DED}$ 공정과 유사한 미세조직적 특성을 가지는 레이 저 클래딩 공정을 통해 고속도 공구강을 제조하였고 이 를 주조 공정으로 제조된 동소재와 $25{ }^{\circ} \mathrm{C}$ 와 $500{ }^{\circ} \mathrm{C}$ 에 서 각각 마모특성을 비교한Rahman [16]등 의 연구결과 를 살펴보면 $25{ }^{\circ} \mathrm{C}$ 에서 진행한 마모실험의 경우 레이저 클래딩을 통해 제조된 시험편은 주조로 제조된 시험편보
다 우수한 마모특성을 보였다. 저자들은 이를 클래딩 공 정의 빠른응고와 냉각에 의한 미세한 탄화물 입자의 분 산와 연관된 것으로 결론지었다. 반면 $500{ }^{\circ} \mathrm{C}$ 의 마모시험 의 경우 주조공정으로 제조된 고속도 공구강이 더 우수 한 마모특성을 보였는데, 이는 미세조직 내의 탄화물이 미세할 경우 고온에서는 쉽게 탈락되기 때문인 것으로 보 인다.비슷한 경향은 선택적 레이저 적층 공정으로 제조된 $\mathrm{Fe}-4 \mathrm{Cr}-8 \mathrm{Mo}-1 \mathrm{VC}$ (wt\%) 공구강의 마모특성을 주조재와 비교한 경우에도 역시 관찰되었다 [17]. 한편, 상기한 본 저자들의 기존 연구[12] 에서는HWS합금의 기초적인 마 모특성을 단일 마모하중과 단일 미끌림속도의 제한적인 조건에서 AISI D2 소재의 거동과 비교분석 하였으나, 향 후 $\mathrm{DED}$ 로 $\mathrm{HWS}$ 합금을 적층하여 금형 등에 적용하기 위해 필요한 다양한 마모조건 하에서의 상세한 마모특성 의 분석은 이루어 지지 않았다. 또한 비교적 짧은 미끌림 거리를 사용하여 짧은 마모시간 동안의 단기적인 마모거 동만을 알아보았기 때문에 실제 금형 등에 적용했을 때 의 장기적인 소재의 마모내구성은 제시되지 않았고 이를 확인할 수 있는 추가적인 연구가 필요하다.

적층공정으로 제조된 금속소재의 마모특성연구는 $\mathrm{DED}$ 공정과 미세조직이 유사한 PBF (Powder bed fusion) 공 정에서도 활발히 진행되고 있는데, 예를 들어 $\mathrm{Bae}$ 등은 [18] 최근 PBF공정으로 적층된 AISI $316 \mathrm{~L}$ 합금의 마모특 성을 냉간압연으로 제조된 동소재와 비교하였다. 실험결과 $\mathrm{PBF}$ 로 제조된 합금이 냉간압연으로 제조된 합금과는 완전 히 상이한 마모거동을 보임을 확인할 수 있었으며, 이는 적층제조에 의한 독특한 미세구조에 따르는 마모기구의 변 화 때문인 것으로 보인다. 따라서 $\mathrm{DED}$ 나 $\mathrm{PBF}$ 와 같은 적 층제조 공정을 내마모성이 요구되는 적용처에 사용하기 위 해서는 다양한 마모조건 하에서의 마모거동을 상세하게 분 석하는 연구가 필요할 것으로 생각된다.

본 연구에서는 $\mathrm{DED}$ 공정으로 적층된 HWS 합금의 내마 모 특성을 다양한 열처리 조건에서 분석하였다. $\mathrm{DED}$ 공정 으로 적층된 $\mathrm{HWS}$ 합금은 향후 기어부품이나 냉간금형, 공 구 등과 같이 금속소재와의 마찰이 상시 일어나는 기계부 품에 활용이 기대되고 있으며, 이러한 환경에서 마모는 주 로 직접적으로 맞닿는 고경도 금속소재 혹은 작동중 불순 물의 유입 등에 의한 세라믹 소재이므로 상대재는 $\mathrm{KS}$ $\mathrm{STB} 2$ 베어링강 및 $\mathrm{ZrO}_{2}$ 2종을 선택하였다. 또한 다양한 적 용처와 작동환경을 고려하여 마모특성에 미치는 마모하중 과 미끌림 속도의 영향을 다양한 하중과 속도 조건 하의 실험을 통해 분석하였다. 이와 함께 마모기구를 미세조직 적 분석을 통해 상세히 고찰하고자 하였다. 
Table 1. Chemical compositions of HWS powder and substrate used for experiments (wt\%).

\begin{tabular}{ccccccccc}
\hline Materials & $\mathrm{C}$ & $\mathrm{Si}$ & $\mathrm{Mn}$ & $\mathrm{Cr}$ & $\mathrm{Mo}$ & $\mathrm{V}$ & $\mathrm{W}$ \\
\hline HWS powder & 1.08 & 1.38 & 0.34 & 7.8 & 1.86 & 2.66 & 1.73 \\
\hline Substrate (KS D3867) & 0.2 & 0.25 & 0.72 & 1.05 & 0.22 & - & - \\
\hline
\end{tabular}

\section{2. 시험방법}

본 연구에서 마모시험에 사용된 HWS 적층 소재는 Rovalma S.A. (Barcelona, Spain) 에서 제공한 분말로 가 스분무법을 통해 제조하여 구형의 입자모양을 가지고 있다. $\mathrm{HWS}$ 분말의 입도는 $50-150 \mu \mathrm{m}$ 의 범위를 가지며 평균입 도는 약 $100 \mu \mathrm{m}$ 였다. 적층을 위한 기판소재로는 구조강 재로 널리 쓰이는 KS D3867 합금강을 사용하였다. DED 공정에 사용된 HWS 분말과 기판소재의 화학조성을 표 1 에 나타내었다. HWS 분말의 합금조성을 살펴보면 $\mathrm{Cr}, \mathrm{V}$, $\mathrm{W}$ 등의 탄화물 생성원소와 함께 다량의 ( $1 \mathrm{wt} \%)$ 탄소가 함유되어 있으므로 미세조직 내에 내마모성에 도움이 되는 탄화물[19]의 형성이 쉽게 일어날 수 있음을 예상할 수 있 다. HWS 분말의 형태 등 자세한 정보는 선행연구[12]에 서 찾아볼 수 있다.

그림 1에 $\mathrm{DED}$ 적층공정을 모식화하여 나타내었다. $\mathrm{DED}$ 적층공정은 $4 \mathrm{~kW}$ 의 $\mathrm{CO}_{2}$ 레이저가 장착되어 있는 InssTek DMT MX3 (InssTek Inc., Korea) 을 활용하였으며, 적층 은 레이저로 형성된 용융풀에 이송가스와 함께 HWS 분말 을 투입하는 방식으로 이루어졌다. 마모샘플은 $100 \times 50 \times$ $10 \mathrm{~mm}^{3}$ 의 기판에 $80 \times 40 \times 1 \mathrm{~mm}^{3}$ 크기의 $\mathrm{HWS}$ 를 층 간 격 $0.25 \mathrm{~mm}$ 로 총 4 층 $\mathrm{DED}$ 적층하여 제작하였다. 여 기서 $\mathrm{BD}$ 는 $\mathrm{DED}$ 공정에서 각 층이 쌓여 올라가는 방향이 며, $\mathrm{TD}$ 는 적층면과 평행한 방향이다. 용융된 금속의 산화 를 방지하기 위해 이송가스와 함께 동축으로 불활성 가스 를 분사하며 적층을 진행하였으며, 이송가스와 동축가스 모 두 고순도 $\mathrm{Ar}$ 가스를 활용하였다. 실험에 사용된 레이저의 빔 직경은 약 $1 \mathrm{~mm}$ 이며, 지그재그 방식으로 각 층을 적 층하였고 적층시 비드간 간격을 $0.5 \mathrm{~mm}$ 로 하였기 때문에 각 $\mathrm{DED}$ 비드는 $0.5 \mathrm{~mm}$ 씩 겹쳐져 있었다. 분말의 공급 량과 레이저 출력, 산화보호 가스 분사속도 등 상세한 $\mathrm{DED}$ 적층공정 조건은 표 2 와 같다. 사용된 조건은 선행연 구[12]에서 기공 등의 결함이 거의 없이 $\mathrm{HWS}$ 를 적층할 수 있었던 DED 공정조건을 참조하여 대부분 그대로 사용 하였고 기공결함의 완전한 제거를 위해 레이저 출력만 소 폭 높인 조건이다.

제작된 HWS 샘플을 각기 다른 조건으로 열처리하여 마

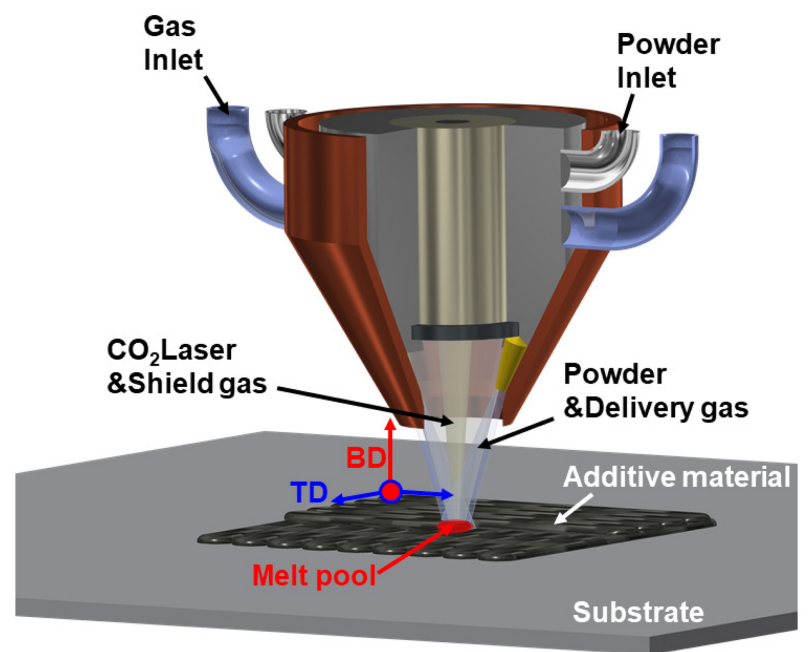

Fig. 1. Schematic of DED process.

Table 2. DED process parameters used for HWS wear specimens.

\begin{tabular}{cc}
\hline Process parameters & Values \\
\hline Laser Power $(\mathrm{W})$ & 830 \\
Powder feed rate $(\mathrm{g} / \mathrm{min})$ & 4.0 \\
Scanning speed $(\mathrm{mm} / \mathrm{min})$ & 850 \\
Powder delivery gas flow rate $(1 / \mathrm{min})$ & 2.5 \\
Coaxial gas flow rate $(1 / \mathrm{min})$ & 8 \\
\hline
\end{tabular}

모시험을 행하였다. 제조사에서 제시한 소결공정을 통해 HWS를 제조할 시 가장 높은 마모특성을 가지게 하는 열 처리 조건은 $1,050{ }^{\circ} \mathrm{C}$ 에서 2 시간 유지 및 담금질 (quenching) 후 $520^{\circ} \mathrm{C}$ 에서 뜨임(tempering)처리 하는 것 이다. 하지만 $\mathrm{DED}$ 적층으로 제조된 $\mathrm{HWS}$ 의 미세조직은 소결된 $\mathrm{HWS}$ 와는 완전히 상이할 것으로 예상되므로, 열처 리가 $\mathrm{DED}$ 적층된 $\mathrm{HWS}$ 에 미치는 영향을 알아보기 위해 열처리 조건이 각기 다른 4 가지 샘플들을 준비하였으며, 각 샘플들의 열처리 조건을 표 3에 나타내었다.

샘플들은 열처리 한 후 미세조직 분석 및 마모시험을 위 해 절단되었다. 먼저 각 샘플의 열처리후 표면을 사포로 연마한 후 비커스 경도시험 (Vickers microhardness, HM220A, Mitutoyo Corp., Japan) 을 각 샘플당 5회 수행하 여 측정하였고, $\mathrm{Cu} \mathrm{Ka}$ 방사광을 통한 $\mathrm{X}$ 선 회절분석법 
Table 3. Heat treatment condition of samples

\begin{tabular}{ccc}
\hline Samples & Quenching & Tempering \\
& $\left(1,050^{\circ} \mathrm{C} /\right.$ water cooling $)$ & $\left(520^{\circ} \mathrm{C} /\right.$ air cooling $)$ \\
\hline As-built & - & - \\
Q & 2 hours & - \\
QT2 & 2 hours & 2 hours \\
QT6 & 2 hours & 6 hours \\
\hline
\end{tabular}

(X-ray diffractometer, XRD, Empyrean, PANalytical $\mathrm{BV}$, Netherlands) 으로 내부의 상변화 동향을 알아보았다. 미세조직 관찰을 위한 샘플들은 적층방향과 수직한 면을 관찰할 수 있도록 절단한 후 마운팅하여 연마하였고, 마지 막으로 $0.05 \mu \mathrm{m}$ 알루미나 슬러리를 이용하여 최종연마 처 리하여 $5 \% \mathrm{HNO}_{3}$ 수용액으로 화학처리하였다. 샘플의 열 처리 조건별 미세조직은 광학현미경 (optical microscope, $\mathrm{OM}$, Eclipse E200, Nikon, Japan) 및 전자주사현미경 (scanning elector microscope, SEM, Aztec HKL, Oxford Inc., UK)을 통해 관찰하였다.

마모샘플들은 적층된 면이 $20 \times 20 \mathrm{~mm}^{2}$ 크기를 가지도 록 절단된 후 사포로 표면 연마처리한 후 시험 직전에 에 탄올로 세척되었다. 마모시험은 ball-on-disk 타입의 마모시 험장비 (JLTB-02, J\&L Tech. Co., Korea)를 사용하여 적 층된 HWS 샘플을 디스크 형태로, 상대재는 ball로 하고 마모트랙의 직경을 $13.6 \mathrm{~mm}$ 로 하여 진행하였으며 실험에 사용된 마모시험법을 그림 2에 모식적으로 나타내었다. 마 모하중과 미끌림 속도가 HWS의 마모특성에 미치는 영향 을 파악하기 위해 상온 건식 분위기에서 $\mathrm{BD}$ 방향으로 하 중을 가하며 as-built 샘플을 $5,20,50 \mathrm{~N}$ 의 하중과 선속 $25,50,100 \mathrm{~mm} / \mathrm{s}$ 의 미끌림 속도로 시험하였다. 이 때 상 대재는KS STB2 베어링강을 사용하였으며, ball의 반경인 $\mathrm{R}_{\mathrm{b}}$ 는 $2.78 \mathrm{~mm}$ 이었는데, HWS와 베어링강의 탄성계수를 $150 \mathrm{GPa}$ 로 근사하여 Hertzian 접촉응력을 계산하면 본 조건에서의 마모하중 $5,20,50 \mathrm{~N}$ 은 각각 627, 994, $1350 \mathrm{MPa}$ 의 접촉응력에 상응한다. 열처리 조건에 따른 마모특성 변화는 Q, QT2, QT6 샘플을 마모하중 $50 \mathrm{~N}$, 미끌림 속도 $100 \mathrm{~mm} / \mathrm{s}$ 의 마모조건으로 시험하여 결과를 as-built 샘플과 비교분석하여 알아보았다. 이와 함께, 마모 상대재에 따른 마모거동의 분석을 위해 as-built 와 QT6

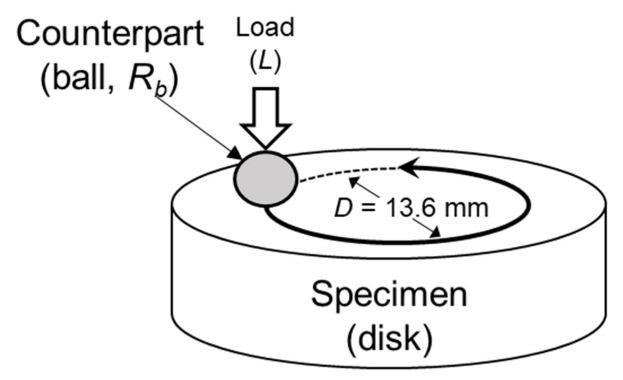

Fig. 2. Schematic of ball-on-disk test used in this study.

샘플을 $5 \mathrm{~N}-25 \mathrm{~mm} / \mathrm{s}, 20 \mathrm{~N}-50 \mathrm{~mm} / \mathrm{s}, 50 \mathrm{~N}-100 \mathrm{~mm} / \mathrm{s}$ 의 3 가지 마모조건에서 베어링강과 $\mathrm{ZrO}_{2}$ 두 가지 상대재로 마 모시험하였으며, 표4에 마모시험에 쓰인 상대재의 물리적 특성을 나타내었다. $\mathrm{ZrO}_{2}$ ball의 $\mathrm{R}_{\mathrm{b}}$ 는 $3.97 \mathrm{~mm}$ 이었으며, 이 때의 마모하중 $5,20,50 \mathrm{~N}$ 은 각각 Hertzian 접촉응 력 $539,856,1161 \mathrm{MPa}$ 에 상응하는 값이다. 총 마모길이 는 모든 마모시험에서 $500 \mathrm{~m}$ 로 고정하였다. 마모시험 이 후의 마모트랙 및 상대재의 상흔 정도, 마모생성물을 $\mathrm{SEM}$ 으로 분석하였으며, 마모트랙의 형태는 3D profiler (3D optical profiler, ContourGT-X, Bruker ASX Pte Ltd., USA) 로 측정하였다.

\section{3. 실험결과 및 고찰}

\subsection{DED 적층된 HWS의 미세조직 및 경도}

그림 3 은 $\mathrm{HWS}$ 와 기판간의 계면 주위의 $\mathrm{OM}$ 이미지와 함께, 주요 합금원소들의 X-선 에너지분산분광 맵을 보여 준다. $\mathrm{OM}$ 이미지에 보이는 검은 점들은 미세조직 관찰을 위한 화학처리시 국부적으로 부식된 부분이다. 열처리 전 후에 계면간의 박리나 크랙의 형성 등의 결함이 발생하지 않음을 확인할 수 있다. As-built 상태의 HWS와 모재의 계면 주위의 합금원소의 분산정도를 보면, HWS합금에 소 량 첨가된 $\mathrm{W}$ 의 경우 공정중 모재에 일부 확산된 것이 확 인되며 그 외 $\mathrm{Cr}, \mathrm{V}, \mathrm{Mo}$ 등의 합금원소는 적층계면을 따 라 조성변화가 뚜렷하게 관찰되는데, 열처리에 따른 주요 합금원소들의 분포 변화는 거의 없었다. 이 결과는 열처리 에 따른 용질원소의 확산은 상당히 제한적이고, 급격한 계 면의 열화 등의 현상은 없다는 것을 암시한다.

Table 4. Physical properties of counter materials used in this study.

\begin{tabular}{cccccc}
\hline Materials & $\mathrm{R}_{\mathrm{b}}(\mathrm{mm})$ & Hardness $(\mathrm{HV})$ & Elastic modulus $(\mathrm{GPa})$ & Poisson's ratio & Density $\left(\mathrm{g} / \mathrm{cm}^{3}\right)$ \\
\hline Bearing steel $($ KS STB2) & 2.78 & 848 & 150 & $0.27-0.3$ & 7.81 \\
$\mathrm{ZrO}_{2}$ & 3.97 & 1300 & 205 & 0.22 & 6.05 \\
\hline
\end{tabular}




\section{(a) As-built}

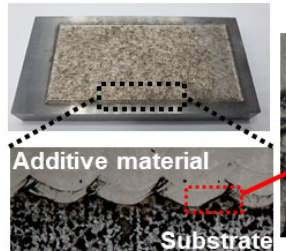

\section{EDS mapping}



(b) Q

(c) QT2

(d) QT6
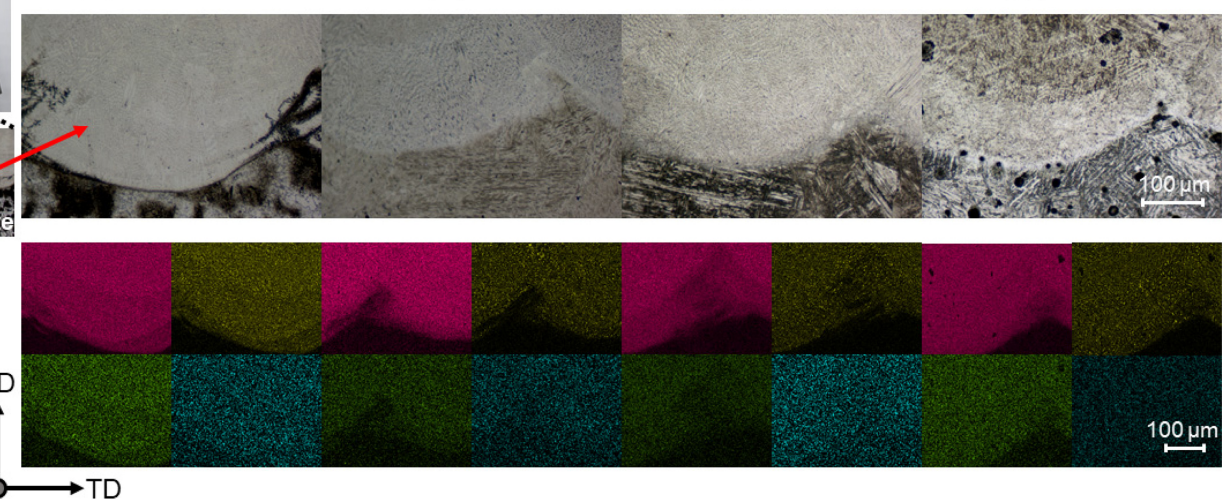

Fig. 3. OM images and energy dispersive X-ray maps near interfaces of HWS samples between deposited layer and substrate.
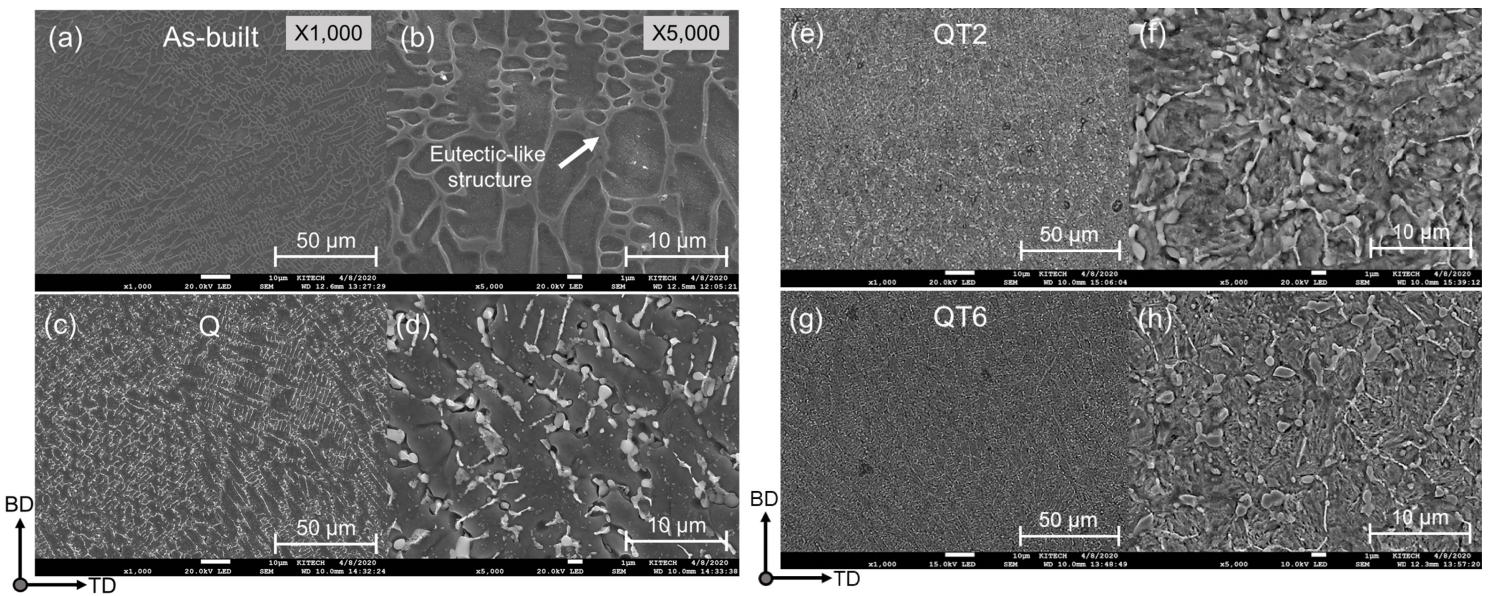

Fig. 4. SEM images of HWS samples. (a, b) As-built, (c, d) Q, (e, f) QT2 and (g, h) QT6.

그림 4에 as-built, Q, QT2, QT6 샘플들의 SEM 미세 조직을 나타내었다. 그림 4(a)의 as-built 상태에서의 HWS 의 미세조직은 수지상정 형태를 확연히 띄고 있는 것을 볼 수 있다. 용접부 등의 급속응고 조직에서 고액계면의 성장 은 온도구배가 비슷할 경우 응고속도가 빨라질수록 planar 에서 점차적으로 cellular, 이후 더욱 빨라지면 dendritic 하게 바뀐다고 알려져 있는데[20], 이를 고려하면 HWS의 미세조직에서 관찰되는 수지상정 형태의 무늬는 빠른 응고 속도에 의한 방향성 응고에 의한 것으로 생각된다. 그림 4(b)의 고배율 (x 5,000) 이미지에서는 수지상정 내부에서 폭이 약 $5 \mu \mathrm{m}$ 로 매우 미세하고 주조조직의 공정구조 (eutectic structure) 와 유사한 형태를 가지는 하부조직이 관찰되는데, 이는 아마도 빠른 냉각속도에 따른 용질원소 의 편석이 일어났기 때문에 생기는 구조일 것으로 짐작된 다. 그림 $4(\mathrm{c}, \mathrm{d})$ 의 $1,150{ }^{\circ} \mathrm{C}$ 수냉처리만 한 샘플 $\mathrm{Q}$ 에서는 탄화물로 보이는 2 차상이 공석구조를 따라 형성되는 것이
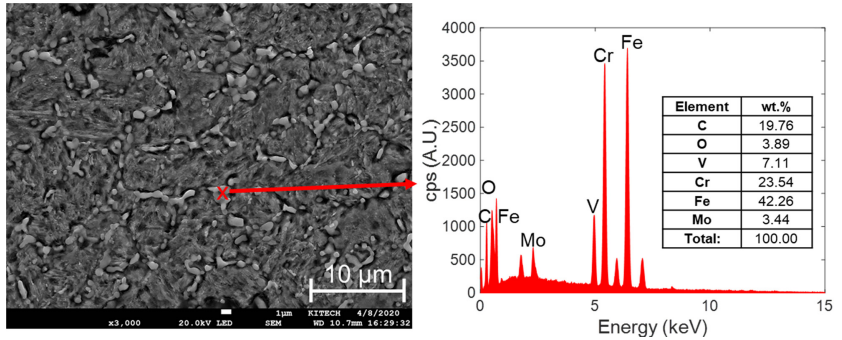

Fig. 5. Energy dispersive X-ray spectrum of carbide in sample QT6

관찰되며, $520^{\circ} \mathrm{C}$ 뜨임처리한 그림 $4(\mathrm{e}, \mathrm{f})$ 와 그림 $4(\mathrm{~g}$, h) 의 샘플 QT2 와 QT6 에서는 기지상의 조직이 복잡한 형태로 변화하는데, 이는 뜨임 마르텐사이트 (tempered martensite) 의 형성에 의한 것으로 생각된다. 한 편, 2 차 상의 형태와 크기는 뜨임처리에서는 큰 변화가 없었다.

샘플 QT6의 2차상의 화학조성을 X-선 에너지분산분광 법으로 분석한 결과를 그림 5 에 나타내었다. 2차상의 스펙 

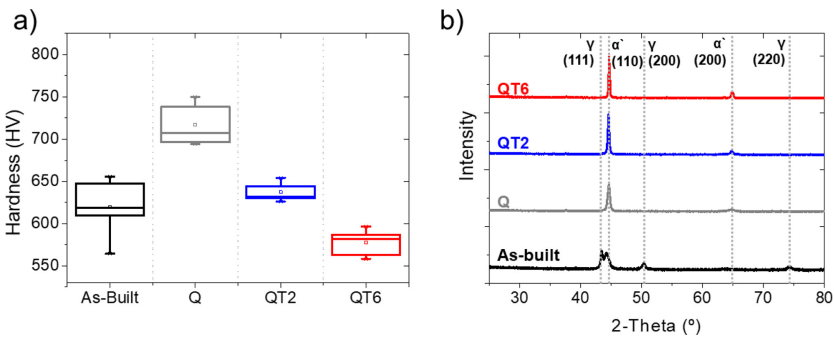

Fig. 6. (a) Hardnesses and (b) XRD patterns of HWS produced by DED in different heat treatment conditions.

트럼에서 $\mathrm{C}, \mathrm{Cr}$ 과 $\mathrm{V}$ 가 다량 검출됨을 확인할 수 있으며, $\mathrm{Mo}$ 의 경우에도 $\mathrm{HWS}$ 원소재의 Mo 함유량인 $1.86 \mathrm{wt} \%$ 보다 유의미하게 높은 $3.44 \mathrm{wt} \%$ 로 분석되었다. HWS와 유사한 조성을 가지는 고속도공구강의 석출물을 전자투과 현미경으로 관찰한 Wei [21]등 의 결과와 비교해 볼 때, $\mathrm{HWS}$ 의 열처리시 석출되는 2 차상은 $\mathrm{M}_{7} \mathrm{C}$ 타입의 탄화물일 가능성이 매우 높아 보인다.

그림 6(a)에 열처리 조건별 HWS 샘플의 경도를 나타내 었다. 경도는 미세조직의 무작위한 부위를 $\mathrm{TD}$ 방향으로 압 입하여 5 회 측정하였다. DED 적층된 HWS는 as-built 상 태에서 경도 평균값 약 $620 \mathrm{HV}$ 를 나타내고 샘플 $\mathrm{Q}$ 의 경 도 평균값은 약 $720 \mathrm{HV}$ 정도이다. 동 소재를 레이저 클래 딩 했을 때의 경도는 약 $600 \mathrm{HV}$ 이고, 열처리를 통해 최 대로 얻을 수 있는 경도값이 $700 \mathrm{HV}$ 언저리 였는데[7], 이와 비교하면 본 연구에서 측정된 $\mathrm{DED}$ 적층된 $\mathrm{HWS}$ 의 경도값은 레이저 클래딩 된 경우보다 소폭 높다. 이 결과 는 아마도 레이저 클래딩에서 용융풀의 크기가 직경 $2.7 \mathrm{~mm}$, 깊이가 $0.5 \mathrm{~mm}$ 인데 비해[7], 본 연구에서의 $\mathrm{DED}$ 는 용융풀의 직경 $1 \mathrm{~mm}$, 각 층의 적층 높이 $0.25 \mathrm{~mm}$ 로 용융풀의 크기가 훨씬 작기 때문에 응고 및 냉각속도가 빨라서 보다 미세한 결정구조를 가지기 때문으 로 생각된다. 용융풀의 급속응고 (적층중 용융부위가 $1 \mathrm{~s}$ 이 후 완전응고)를 가정하여 적층속도를 통해 냉각속도를 유 추해 보면 면 본 연구에서의 HWS의 냉각속도는 대략 7 $\times 10^{4}{ }^{\circ} \mathrm{C} / \mathrm{s}$ 정도로 추산된다 [22].

한 편, as-built 상태에서의 경도값은 측정위치에 따라 상 당한 편차를 보여 $570-650 \mathrm{HV}$ 의 넓은 분포를 가지고 있는데, 이는 국부적인 입열과 빠른 응고로 내부에 복잡한 수축 잔류응력이 형성되었기 때문으로 사료된다. 샘플 $\mathrm{Q}$ 의 경우는 as-built 와 비교시 현저하게 줄은 경도값 편차를 보여주는데, 이는 열처리에 의해 잔류응력이 완화되었기 때 문으로 풀이된다. 샘플 $\mathrm{QT} 2$ 와 $\mathrm{QT} 6$ 의 경도를 샘플 $\mathrm{Q}$ 와 비교해 보면, $520^{\circ} \mathrm{C}$ 뜨임 처리는 $\mathrm{DED}$ 된 $\mathrm{HWS}$ 의 경도
를 급격히 낮춘다는 것을 알 수 있으며, 뜨임 시간이 2시 간인 QT2 의 경우 담금질 처리로 $720 \mathrm{HV}$ 까지 높아졌던 경도가 as-built와 비슷한 수준인 $630 \mathrm{HV}$ 정도로 다시 감 소하고 뜨임시간을 6시간으로 늘린 QT6의 경우 as-built보 다도 오히려 낮은 $575 \mathrm{HV}$ 정도의 경도를 보였다. 이는 레 이저 클래딩으로 $\mathrm{HWS}$ 를 적층했을 때 $550^{\circ} \mathrm{C}$ 에서 뜨임 처리하면 경도가 상승했던 Leunda 등[7]의 연구결과와 상 반된 것이다. 이 결과는 $\mathrm{DED}$ 로 $\mathrm{HWS}$ 를 적층했을 때의 빠른 냉각속도에 의한 미세한 조직 때문에 열처리에 따른 조직변화가 클래딩 된 동 소재와 다르게 나타나는 경향 때 문으로 사료된다. 미세조직이 DED 공정과 매우 유사한 선 택적 레이저 적층된 maraging steel 의 사례[23]에서 집속 된 레이저 용융을 통해 형성된 미세한 조직은 보다 낮은 온도에서도 활발하게 상변화 등이 일어나서 일반적으로 쓰 이는 열처리 조건보다 낮은 온도에서도 동일한 수준의 열 처리 효과를 얻을 수 있음이 관찰되었는데, 아마도 동일한 경향이 $\mathrm{DED}$ 로 적층된 $\mathrm{HWS}$ 에서도 나타나는 것으로 보인 다. 따라서 만약 $\mathrm{DED}$ 로 적층된 $\mathrm{HWS}$ 의 담금질 및 뜨임 처리가 반드시 필요할 때에는 뜨임온도를 일반적인 조건보 다 낮추는 등의 연구가 앞으로 필요할 것으로 생각된다.

그림 6(b) 의 XRD 패턴을 보면, as-built 상태에서의 HWS는 $\alpha^{\prime}$-마르텐사이트와 함께 상당한 양의 잔류 $\gamma$-오스테 나이트 상을 가지고 있음을 알 수 있으며, 잔류 오스테나 이트 상은 마르텐사이트보다 일반적으로 경도가 훨씬 낮으 므로, 이는 그림 6(a)에서 관찰된 as-built 상태에서의 경도 값 편차를 일으키는 또다른 원인으로 볼 수 있다. 담금질 처리된 $\mathrm{Q}$ 와 $\mathrm{QT2}$, QT6 샘플들의 XRD 패턴은 $\alpha$ '마르텐 사이트의 회절패턴만을 나타내기 때문에 열처리시 미세조 직은 대부분 마르텐사이트로 이루어져 있음으로 판단된다. 선행연구[12]에서 DED적층된 HWS는 담금질 및 뜨임처리 후 오히려 파괴인성이 as-built에 비해 낮추어지는 결과를 보였는데, 그림 6(b)의 XRD 패턴을 보면 열처리에 의한 파괴인성의 저하는 $\alpha^{\prime}$-마르텐사이트보다 연성이 높은 잔류 $\gamma$-오스테나이트가 열처리에 의해 대부분 $\alpha^{\prime}$-마르텐사이트로 바뀌었기 때문으로 생각된다.

\subsection{As-built 상태에서의 마모거동}

그림 7은 as-built 샘플의 $500 \mathrm{~m}$ 마모 전후의 중량변화 를 마모 조건별로 비교한 그래프이다. 상대재는 베어링강 을 사용하였다. As-built 샘플의 마모 전후 중량변화는 Hertzian 접촉응력 $1,350 \mathrm{MPa}$ 에 상응하는 고응력 조건 $(50 \mathrm{~N})$ 에서도 $500 \mathrm{~m}$ 의 미끌림 거리 이후 $3 \mathrm{mg}$ 이하의 중량변화만을 보였으며 이는 $\mathrm{DED}$ 적층된 HWS가 as- 
(a)

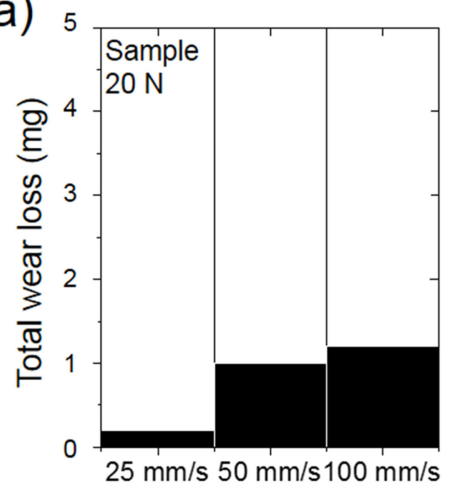

(b)

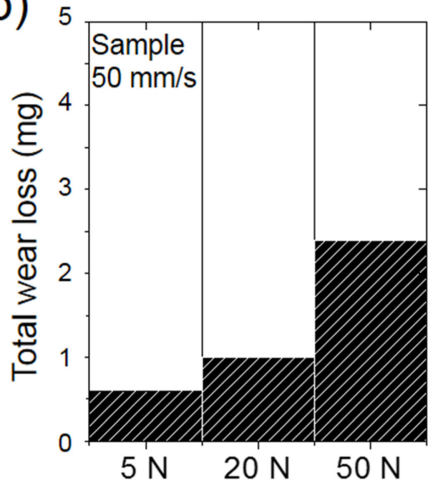

(c)

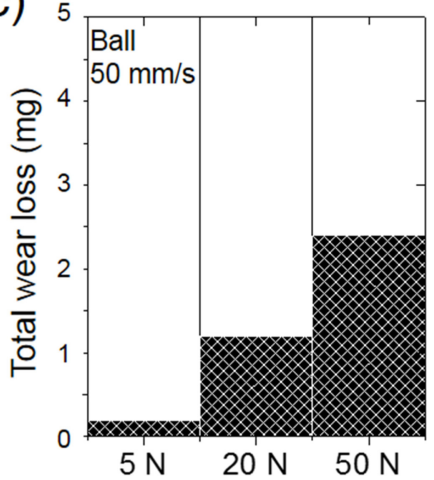

Fig. 7. Comparisons of total wear weight losses in terms of wear loads and sliding speeds. (a) Wear weight losses of samples according 1 sliding speeds, (b) wear loads and (c) bearing steel counter material.

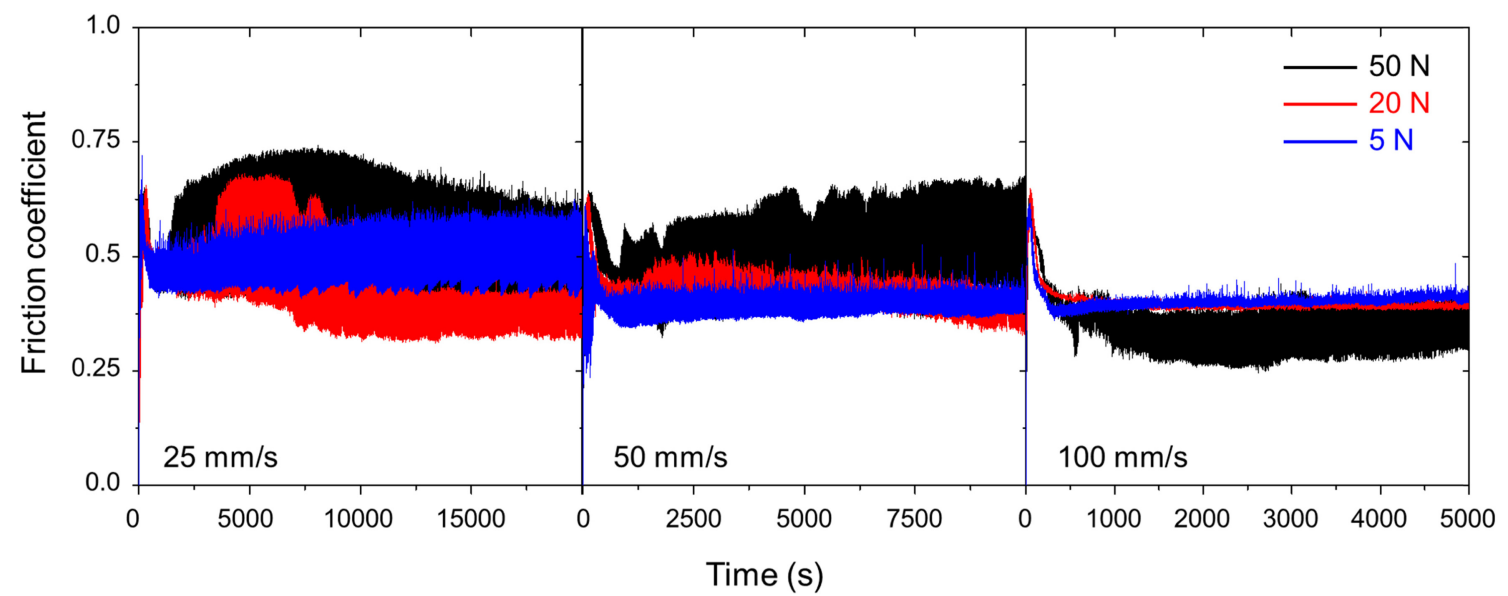

Fig. 8. Evolutions of friction coefficients as a function of time, measured from ball-in-disk wear tests of as-built samples with different wear test conditions.

built 상태에서도 매우 우수한 마모저항성을 가지고 있다는 사실을 지칭한다. 한 편, 본 연구에서는 $\mathrm{DED}$ 적층된 $\mathrm{HWS}$ 의 마모거동만을 비교 분석하였으나, 선행연구[12]에 서 제시한 바와 같이 HWS의 마모저항성은 as-built 상태 에서도 열처리된 KS STD11 냉간금형강의 마모저항성 보 다 높은 우수한 특성을 가지고 있다. 그림 7(a)은 마모하 중 $20 \mathrm{~N}$ 에서 미끌림 속도에 따른 중량변화를 나타낸 것이 다. 마모에 의한 중량변화는 미끌림 속도가 $25 \mathrm{~mm} / \mathrm{s}$ 에서 $50 \mathrm{~mm} / \mathrm{s}$ 로 빨라질 경우에 확연히 증가하였고, $50 \mathrm{~mm} / \mathrm{s}$ 에서 $100 \mathrm{~mm} / \mathrm{s}$ 로 증가할 때에는 큰 차이가 없었으므로 선속 $50 \mathrm{~mm} / \mathrm{s}$ 이상의 속도에서는 미끌림 속도의 영향이 다 소 제한되는 것으로 보인다. 그림 7(b)는 미끌림 속도 50 $\mathrm{mm} / \mathrm{s}$ 에서 마모하중에 따른 중량변화를 나타내었다. 마모 하중이 증가함에 따라 샘플의 중량변화가 선형적으로 증가 하는 경향이 명확하게 관찰되었다. 그림 7(c)의 상대재인 베어링강 ball의 중량변화를 보면 베어링강 ball의 중량변
화는 마모하중에 지배적인 것을 확인할 수 있다. Ball의 중량변화는 마모하중에 따라 선형적으로 증가하는 경향이 관찰되었다. 샘플과 베어링강 ball의 중량변화를 상대비교 하면 샘플과 ball의 마모 중량변화가 $0.5-2 \mathrm{mg}$ 의 비슷한 수준이라는 것을 확인할 수 있는데, 이 결과는 본 실험에 사용된 베어링강 ball이 표 4에 나타낸 것 처럼 $848 \mathrm{HV}$ 의 경도값을 가지는 고경도 소재임을 감안하면 $\mathrm{DED}$ 적층 된 HWS의 내마모특성이 as-built 상태에서도 매우 우수함 을 암시한다.

그림 8에 as-built 시험편의 미끌림 시간에 따른 마찰계 수의 변화를 각기 다른 속도와 하중조건에서 측정하여 나 타내었다. 미끌림 속도가 선속으로 $25 \mathrm{~mm} / \mathrm{s}$ 일 때에 측정 된 마찰계수는 상당한 진폭을 가지며 요동하는 경향을 보 였으며 하중이 증가할수록 진폭이 상대적으로 커지는 경향 을 보였다. 이 결과는 그림 7 의 미끌림 속도가 $25 \mathrm{~mm} / \mathrm{s}$ 일 때의 $1 \mathrm{mg}$ 이하의 낮은 마모량을 고려하면 마모시험편 
표면에 연마로 미처 제거되지 못한 미세한 요철들이 시험 편의 마모량이 극도로 낮으므로 시험 도중에도 없어지지 않고 기기가 측정하는 마찰계수에 영향을 주는 결과로 이 해할 수 있다. 미끌림 속도가 $50 \mathrm{~mm} / \mathrm{s}$ 와 $100 \mathrm{~mm} / \mathrm{s}$ 일 때에는 마모하중이 $5 \mathrm{~N}$ 과 $20 \mathrm{~N}$ 인 경우에는 실험 초기에 마찰계수가 약간 요동한 후에는 안정화되어 진폭이 거의 없이 안정적인 마찰이 일어나는 거동을 보이지만, 마모하 중이 $50 \mathrm{~N}$ 인 경우에는 상당한 마모시간이 흐른 후에도 측 정되는 마찰계수가 안정화 되지 않고 진동을 보이는 데, 이와 같은 경향은 그림 7(b) 에 나타낸 것 처럼 마모하중 이 $50 \mathrm{~N}$ 일 때에는 상대재인 ball의 마모가 상당 수준 일 어나므로 ball의 마모에 따른 마찰면의 거동변화 때문인 것 으로 생각된다. 마모가 진행되면서 마찰계수가 안정화 되 는 미끌림 속도 50 과 $100 \mathrm{~mm} / \mathrm{s}$, 마모하중 5 와 $20 \mathrm{~N}$ 의 조건에서는 마찰계수 0.4 전후에서 안정화 되며, 이는 윤 활재 없이 마모가 거의 일어나지 않을 때의 강재간의 이론 적 마찰계수인 0.39 [24] 에 근접한 수치이다.

\section{3. 열처리 조건에 따른 마모거동}

그림 9 에 열처리 조건별 마모실험 결과를 마모하중 50 $\mathrm{N}$, 미끌림 속도 $100 \mathrm{~mm} / \mathrm{s}$ 의 조건에서 분석하여 비교하였 다. 상대재가 베어링강일 경우 $\mathrm{DED}$ 적층된 $\mathrm{HWS}$ 의 마모 특성은 열처리를 하는 경우가 뜨임 열처리의 유무와는 관 계 없이 as-built 보다 열처리를 했을 때 매우 낮은 마모 특성을 나타내는 것을 확인할 수 있다. 그림 9(a)에 나타 낸 샘플의 마모 전후 중량변화를 보면 as-built 샘플에서 $2 \mathrm{mg}$ 정도였던 중량변화가 샘플 $\mathrm{Q}$ 의 경우 동 조건에서 약 $41 \mathrm{mg}$ 으로 20 배 이상 늘었으며 QT2 와 QT6 의 경우에 도 $20 \mathrm{mg}$ 정도로 as-built 샘플과 비교하여 10 배 가량의 중량변화를 보였다. 상대재인 베어링강 ball의 마모의 경우 에도 그림 $9(\mathrm{~b})$ 에 나타낸 것처럼 샘플 $\mathrm{Q}$ 를 실험할 경우에 다른 샘플들 보다 더 큰 중량변화를 보였으며 QT6의 경 우 베어링강 ball의 마모는 as-built샘플을 실험할 때와 유 사한 수준의 ball의 마모를 보였다. 동일한 경향은 그림 9(c)에 나타낸 각 샘플의 마모트랙 단면의 형상에서도 나 타나는데, 각 샘플의 마모트랙은 as-built 샘플의 경우 상대 적으로 거의 변화가 없는 반면 (트랙 깊이 $1.08 \mu \mathrm{m}$ ) 담금 질처리만 한 샘플 $\mathrm{Q}$ 의 경우 $78.94 \mu \mathrm{m}$ 의 매우 깊은 마모 트랙을 보였고 뜨임처리가 추가된 샘플 QT2와 QT6의 마 모트랙은 Q보다는 상대적으로 얕으나 as-built 보다는 매우 깊은 약 $50 \mu \mathrm{m}$ 전후의 깊이를 가지고 있다. 한 편, 마모 트랙의 너비에서는 샘플별로 큰 차이는 보이지 않았다. 마 모트랙의 깊이가 큰 차이를 보임에도 마모트랙의 너비가
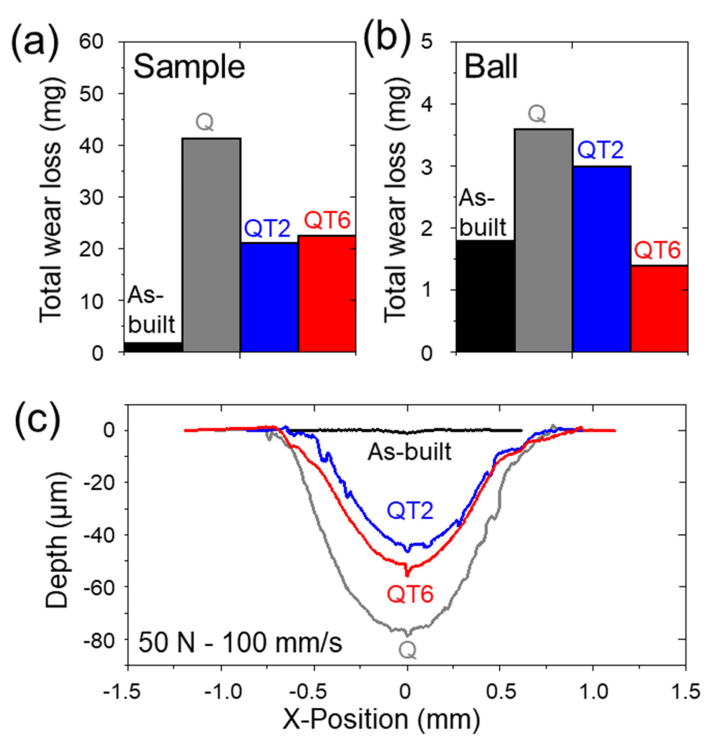

Fig. 9. Comparisons of wear test results between samples as-built, Q, QT2 and QT6, tested with a wear load of $50 \mathrm{~N}$ and a linear sliding speed of $100 \mathrm{~mm} / \mathrm{s}$. (a) Total wear losses of samples, (b) total wear losses of counter material and (c) worn surface profiles.

샘플별로 차이가 없는 경향은 그림 9(b)의 상대재인 ball 의 마모 전후 무게변화가 샘플의 무게변화와 거의 유사한 양상으로 바뀌는 것과 관련이 있을 것으로 유추된다. 만약 상대재인 ball이 HWS 샘플보다 충분히 단단하여 마모 도 중 ball의 형태의 변화가 거의 없다면 마모트랙의 깊이가 깊어지면 질수록 샘플과 상대재가 맞닿는 면적이 넓어지며 마모트랙의 형태 역시 점점 넓어질 것이다. 하지만 그림 9(b)에서 보여지듯 상대재가 베어링강일 경우 상당한 양의 상대재 역시 시험 도중 마모되는 것을 알 수 있는데, 열처 리 공정 이후의 샘플들의 경우에는 샘플과 ball 중 특정소 재에서 일방적인 중량변화가 발생하지 않았고, 선행연구 [25-27] 의 사례와 유사하게 샘플과 ball모두 유사한 마모 속도가 발생하는 것이 확인되었다. 이는 상대재인 ball 역 시 마모시험에서 마모되며 맞닿는 부분의 형태가 변함을 시사한다. 이 경우에는 ball이 마모시험 초기에 샘플과 국 부적으로만 접촉하며 맞닿는 부분이 우선 마모되고 이후 ball의 마모로 면대 면 형태의 마찰을 보일 것으로 예상되 는데, ball이 일정 수준 마모된 후 형태가 안정되는 경우 샘플의 마모는 마모트랙의 너비방향으로의 확장이 거의 없 이 깊이 방향으로 마모트랙이 확장될 수 있을 것으로 예상 되며, 본 실험의 결과는 상대재가 베어링강일 경우의 위와 같은 상호작용에 기인하는 것으로 사료된다.

그림 10 에 마모하중 $50 \mathrm{~N}$, 미끌림 속도 $100 \mathrm{~mm} / \mathrm{s}$ 하의 as-built, Q, QT2 및 QT6 샘플의 마찰계수 변화를 


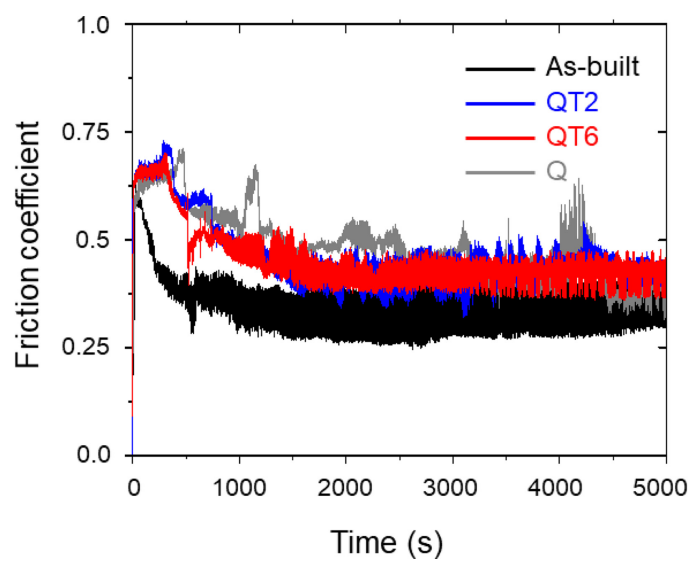

Fig. 10. Evolutions of friction coefficients with time during wear tests of samples as-built, Q, QT2 and QT6, tested with a wear load of $50 \mathrm{~N}$ and a linear sliding speed of $100 \mathrm{~mm} / \mathrm{s}$.

비교하여 나타내었다. As-built 샘플과 달리 열처리된 Q, $\mathrm{QT} 2$ 와 QT6 샘플들은 마모시험 초기의 마찰계수가 상당 히 높은 것이 확연히 보여진다. 이는 마모시험 초기에 asbuilt 샘플보다 열처리 된 샘플들의 마모속도가 상당히 높 음을 간접적으로 암시한다. 마모시간이 지나면서 열처리된 샘플들의 마찰계수는 as-built 샘플과 마찬가지로 안정화 되 어 마모시간 $2,000 \mathrm{~s}$ 이후에는 큰 변화가 보이지 않는데, 이 때의 안정화된 마찰계수는 약 0.4 정도로 일반적인 강 재간의 이론적 마찰계수인 0.39[24] 와는 잘 일치하지만, as-built 샘플보다는 상대적으로 약간 높은 마찰계수를 나 타낸다. 이는 마모 초기 뿐만 아니라 상당한 수준의 마모 가 일어난 후에도 열처리된 샘플들에서 지속적으로 마모가 일어남을 나타낸다.

그림 11에 마모하중 $50 \mathrm{~N}$, 미끌림 속도 $100 \mathrm{~mm} / \mathrm{s}$ 로마 모시험한 샘플들의 마모트랙과 마모생성물의 SEM 분석 결 과들을 비교하여 나타내었다. 열처리된 샘플들의 마모트랙 과 비교하여 as-built샘플의 마모트랙은 상대적으로 폭이 좁 은 마모상흔을 보이며, 500 배의 배율로 관찰했을 때 절삭 마모기구(abrasive wear mechanism)[21]에 의한 것으로 생각되는 마모진행방향으로의 홈들과 함께, 상대재인 베어 링강이 마모트랙 표면에 묻어나는 응착마모기구 $[16,28]$ 형 태의 상흔 역시 확연히 관찰된다. As-built 샘플의 마모생 성물의 경우 절삭마모기구에 의해 발생한 것으로 생각되는 미소파편형태의 마모생성물 만이 관찰된다. 한 편, 열처리 된 $\mathrm{Q}, \mathrm{QT} 2$ 와 QT6 샘플들에서는 공통적으로 산화피막의 형성 및 이의 박리에 의한 특징적인 마모상흔 형태가 관찰 되며, 마모생성물 역시 미소파편형태의 생성물과 함께 박 리에 의한 박판형태의 조대한 생성물이 함께 관찰되는데,



Fig. 11. SEM images of wear tracks and debris of samples (a) asbuilt, (b) Q, (c) QT2 and (d) QT6, with a wear load of $50 \mathrm{~N}$ and a linear sliding speed of $100 \mathrm{~mm} / \mathrm{s}$.

이는 열처리된 샘플들의 주요 마모기구는 마모중 일어나는 산화 및 이에 따른 산화피막의 박리라는 것을 의미한다. 이와 같은 경우 마모속도가 샘플의 경도와 무관하게 산화 속도에 크게 의존하는 결과를 기존의 연구들 에서도 찾아 볼 수 있다 [19, 29-31]. 예로Hashemi [19]등의 연구결과 를 참조해 보면 산화층의 박리에 의한 마모기구가 활성화 되면 샘플의 경도가 높고 낮음에 상관없이 마모속도가 높 아지는 경향을 보였으며, 이러한 이유는 고경도 소재의 경 우 순수절삭마모기구를 통한 마모속도는 매우 낮음에 비해 화학적인 반응에 의한 산화층의 형성은 비교적 쉽게 일어 나기 때문이다.

그림 9에서 as-built 샘플은 열처리된 다른 샘플에 비해 확연히 높은 마모특성을 나타내었는데, 그림 11의 결과를 보면 열처리 이후의 급격한 마모특성의 변화는 열처리된 샘플이 상대재가 베어링강일 경우 완전히 다른 마모기구를 가지기 때문이라는 것을 알 수 있다. 이 결과는 적층된 $\mathrm{HWS}$ 가 다른 고경도 강재와의 마찰환경 하에 있을 때에는 열처리를 하면 오히려 마모특성이 저하된다는 것을 의미하 며, 따라서 적층재가 실제로 처하는 환경에 따라 열처리 조건이 주의 깊게 선택되어야 한다는 점을 암시한다. 만약 부득이하게 HWS 적층재를 고경도 강재와의 마찰환경에서 열처리 이후 사용해야 하는 경우라면 산화피막의 형성을 더디게 하는 윤활처리 등의 추가적인 대책이 필요할 것으 로 생각된다. 한편, 샘플 $\mathrm{Q}$ 는 유사한 마모기구를 가지는 샘 플 QT2와 QT6와 비교하여 경도가 매우 높음에도 불구하 고 오히려 가장 낮은 마모특성을 보였는데, 이는 산화피막 의 형성과 박리가 주요 마모기구인 샘플 Q, QT2, QT6의 경우에는 뜨임처리를 통해 재료의 인성을 향상시키는 것이 


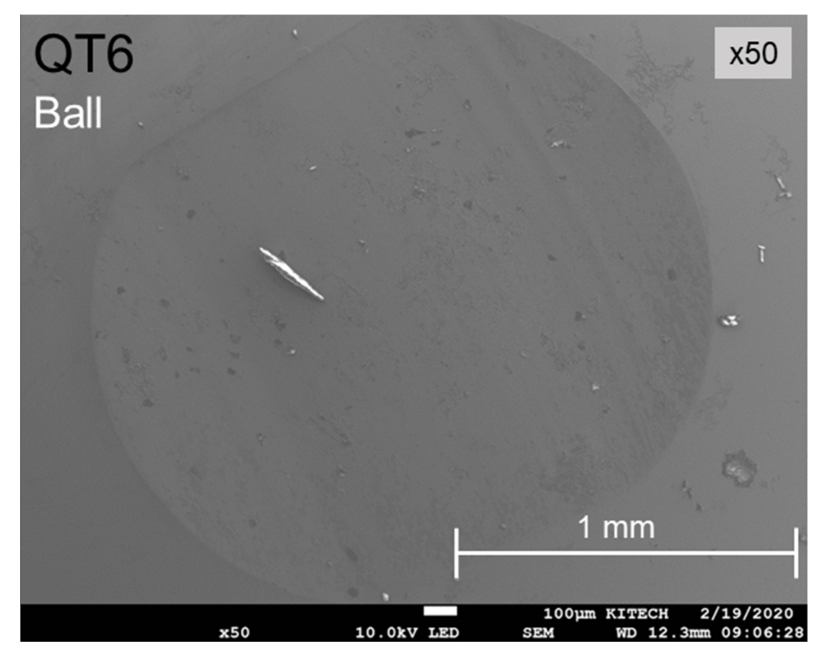

Fig. 12. SEM image of wear scars morphology of counterpart bearing steel ball after wear test of sample QT6 with a wear load of $50 \mathrm{~N}$ and a linear sliding speed of $100 \mathrm{~mm} / \mathrm{s}$.

마모속도를 줄이는 데에 도움이 되기 때문으로 생각된다.

그림 12은 샘플QT6의 마모시험에 사용된 상대재인 베어 링 강 ball의 SEM분석결과를 보여준다. 상대재인 ball의 마 모시험 후 형태변화는 as-built 를 포함한 모든 실험조건에 서 큰 차이가 없이 유사한 결과를 나타내었다. 그림 12 은 베어링강을 상대재로 사용할 경우 상당한 수준의 ball의 마 모 역시 동반된다는 것을 보여준다. 마모시험 이후의 ball의 표면은 맞닿는 면이 상당히 마모되어 편평한 형태로 변화한 것을 알 수 있으며, 마모된 부분의 폭은 약 $1.5 \mathrm{~mm}$ 정도
인데 이는 그림 $9(\mathrm{c})$ 에서 관찰된 HWS 샘플들의 마모트랙 의 너비와 비슷한 크기이며 이를 통해 ball의 마모에 따라서 맞닿는 면적이 비교적 큰 변화 없이 유지되어 마모트랙의 너비방향보다는 깊이방향으로 마모가 진행된다는 사실을 알 수 있다. Ball의 마모면은 눈에 띄는 홈이나 박리의 흔적이 없이 말끔한 형태를 띄며, 이를 통해 베어링강 ball의 마모 는 순수절삭마모에 의한 것임을 짐작할 수 있다.

실험에 사용된 베어링강 ball의 경도는 표 4에 제시한 바와 같이 $848 \mathrm{HV}$ 정도로, 열처리 유무에 상관 없이 HWS 샘플보다 상당히 높다. HWS 샘플들 보다 높은 경 도를 가지고 있음에도 베어링강 ball이 함께 마모되는 이 유는 아마도 그림 5에서 관찰된 바와 같이 HWS 샘플은 미세조직 내에 국부적으로 높은 경도를 띨 수 있는 탄화물 등이 형성되어 있기 때문으로 생각되며, HWS와 베어링강 과의 마모는 경도가 높은 탄화물에 의한 상대재 ball의 마 모파편의 탈락에 상당한 영향을 받았을 것으로 생각된다.

\subsection{HWS의 마모에 미치는 상대재의 영향}

그림 13에 상대재 ball을 베어링강과 $\mathrm{ZrO}_{2}$ 두 가지로 달리 하여 여러 가지 마모하중과 미끌림 속도 하에서의 as-built와 QT6 샘플의 마모특성 분석 결과를 비교하였다. 그림 13(a) 의 마모에 의한 샘플의 중량변화를 보면, 마모 하중과 미끌림 속도가 각각 $5 \mathrm{~N}-25 \mathrm{~mm} / \mathrm{s}$ 와 $20 \mathrm{~N}-50$ $\mathrm{mm} / \mathrm{s}$ 일 경우에는 as-built와 QT6 샘플 모두 상대재와 상 관 없이 마모에 의한 중량변화가 매우 미미하였다. $50 \mathrm{~N}$ 하
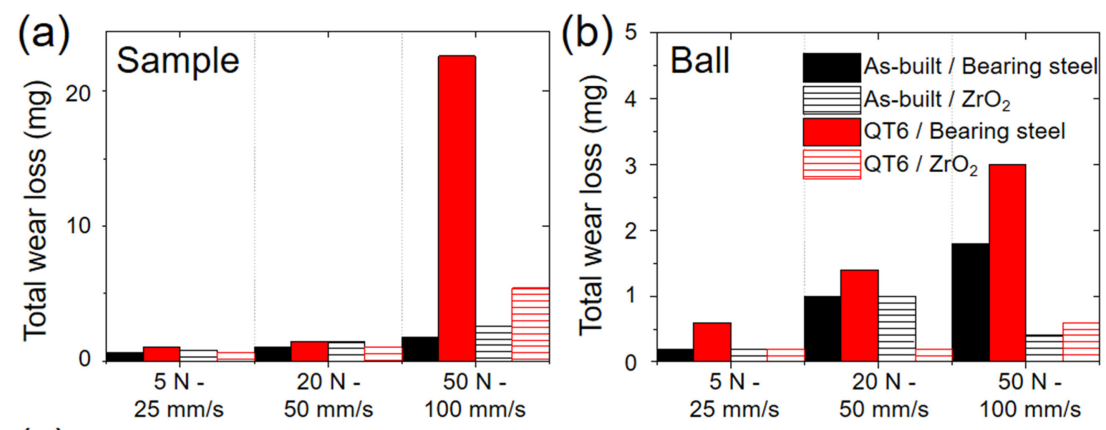

(c)

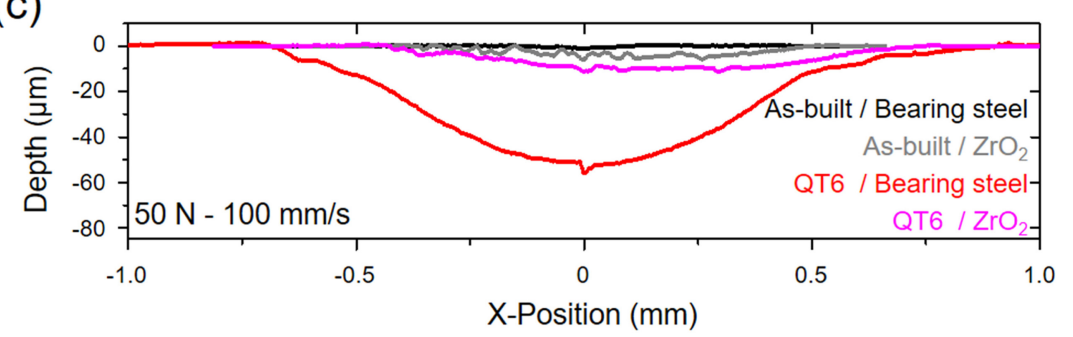

Fig. 13. Comparisons of wear test results between different counterpart materials of bearing steel and $\mathrm{ZrO}_{2}$ for samples as-built and QT6. (a) Total wear losses of samples under different wear loads and speeds, (b) total wear losses of counter materials and (c) worn surface profiles. 


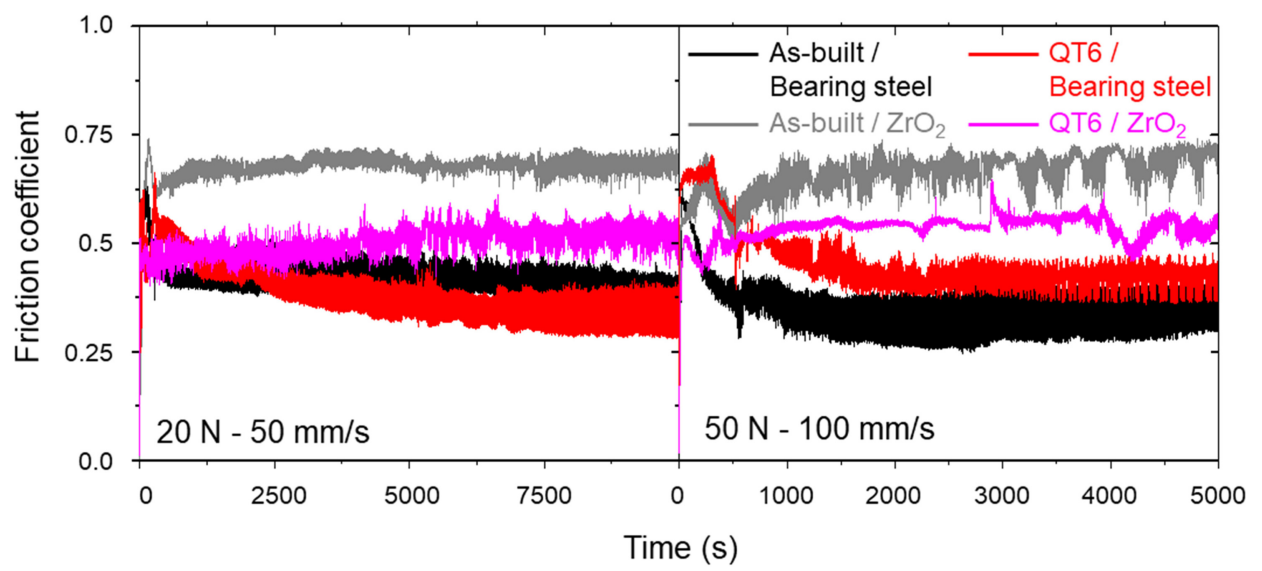

Fig. 14. Evolutions of friction coefficients with time obtained from wear tests of samples as-built and QT6 against different counterpart materials of bearing steel and $\mathrm{ZrO} 2$ under wear loads and speeds of $20 \mathrm{~N}-50 \mathrm{~mm} / \mathrm{s}$ and $50 \mathrm{~N}-100 \mathrm{~mm} / \mathrm{s}$.

중과 $100 \mathrm{~mm} / \mathrm{s}$ 의 미끌림 속도로 마모를 진행한 경우에는 상당한 수준의 마모 중량변화가 발생하는 것을 알 수 있으 며, 상대재와 열처리 유무에 따라서도 마모정도가 크게 바 뀌는 것을 확인할 수 있다. 마모 하중과 미끌림 속도에 무 관하게, as-built 샘플의 경우 상대재가 베어링 강인 경우 보다 $\mathrm{ZrO}_{2}$ 일 때 비교적 중량변화가 컸고 $\mathrm{QT} 6$ 의 경우 반대로 $\mathrm{ZrO}_{2}$ 를 상대재로 사용했을 때 중량변화가 작았다. 가장 큰 마모 중량변화를 보인 $50 \mathrm{~N}$ 하중과 $100 \mathrm{~mm} / \mathrm{s}$ 의 미끌림 속도의 조건에서 as-built 샘플의 경우 베어링 강을 상대재로 사용했을 때는 $1.8 \mu \mathrm{g}$ 의 중량변화만을 보인 데 반해 $\mathrm{ZrO}_{2}$ 의 경우 1.5 배 정도 높은 $2.6 \mu \mathrm{g}$ 의 중량변화를 보였다. 반면에 담금질 및 뜨임 열처리를 진행한 샘플 QT6의 중량변화는 베어링 강 상대재인 경우의 $22.6 \mu \mathrm{g}$ 에 비해 매우 낮은 $5.4 \mu \mathrm{g}$ 의 중량변화가 $\mathrm{ZrO}_{2}$ 상대재를 사용 했을 때 관찰되었다. 상대재인 ball의 중량변화는 그림 13(b)에 나타내었는데, 베어링 강의 경우 as-built 샘플에 비해 QT6와 마찰할 때 더욱 큰 ball의 마모가 나타나는 데 비해 $\mathrm{ZrO}_{2}$ ball 의 경우 HWS 샘플의 열처리 유무와 큰 상관관계 없이 들쑥날쑥한 마모거동을 보이며 동 조건 에서 베어링 강을 사용했을 때의 ball의 마모 중량변화는 상대적으로 매우 낮았는데, 이는 $\mathrm{ZrO}_{2}$ ball의 경도가 약 $1,300 \mathrm{HV}$ 로 $\mathrm{HWS}$ 나 베어링 강 소재에 비해 매우 높기 때문으로 생각된다. 그림 $13(\mathrm{c})$ 는 마모하중 $50 \mathrm{~N}$, 미끌림 속도 $100 \mathrm{~mm} / \mathrm{s}$ 의 조건에서 상대재를 베어링 강과 $\mathrm{ZrO}_{2}$ 로 하였을 때의 HWS의 마모트랙 단면 형상을 나타낸다. Asbuilt 샘플의 경우 상대재가 베어링 강일 때 트랙의 마모깊 이가 $1.08 \mu \mathrm{m}$ 인데 비해 상대재가 $\mathrm{ZrO}_{2}$ 일 때는 약 6 배 높은 $5.95 \mu \mathrm{m}$ 의 마모깊이를 보였다. 반면에, QT6의 경우 상대재가 베어링강인 경우와 $\mathrm{ZrO}_{2}$ 인 경우 마모깊이가 각
각 $55.92 \mu \mathrm{m}$ 와 $11.46 \mu \mathrm{m}$ 이며, 그림 $13(\mathrm{a})$ 의 중량변화 와 같이 상대재의 변화에 따른 마모거동의 변화가 열처리 유무에 따라 완전히 반대되는 경향을 보이는 것을 재차 확 인할 수 있다.

그림 14에 각기 다른 상대재를 통한 as-built샘플과 샘플 QT6의 미끌림 시간에 따른 마찰계수 변화를 실험조건 $20 \mathrm{~N}-50 \mathrm{~mm} / \mathrm{s}$ 와 $50 \mathrm{~N}-100 \mathrm{~mm} / \mathrm{s}$ 두 조건에 대해 나 타내었다. 상대재가 베어링 강일 경우 마모가 진행됨에 따 라 마찰계수가 초기에는 급격히 감소하다가 시간이 지나면 서 점차 안정되는 반면, 상대재가 $\mathrm{ZrO}_{2}$ 일 경우 실험 조 건과 $\mathrm{HWS}$ 의 열처리 유무에 상관 없이 마찰계수가 시간이 지나면서 낮아지지 않거나 오히려 천천히 증가하는 경향이 확연하게 나타난다. 이 결과는 상대재가 $\mathrm{ZrO}_{2}$ 인 경우 베어 링 강과 달리 마모 도중 ball의 마모 정도가 매우 낮아 마모시험 중 HWS가 마모됨에 따라 구형의 형태를 유지하 고 있는 ball 과 샘플이 접촉하는 면적이 점점 늘어남에 의한 것으로 생각된다.

그림 14에서 상대재가 $\mathrm{ZrO}_{2}$ 일 경우만을 놓고 비교해 보면 as-built 샘플이 QT6 보다 마찰계수가 확연히 높은 것을 알 수 있으며, 이러한 현상은 마모하중과 미끌림 속 도가 각각 $20 \mathrm{~N}-50 \mathrm{~mm} / \mathrm{s}$ 일때와 $50 \mathrm{~N}-100 \mathrm{~mm} / \mathrm{s}$ 일 때 모두 동일하게 관찰된다. 한 편, 그림 13(a)의 마모 중 량변화를 상기 두 조건에서 살펴보면 $20 \mathrm{~N}-50 \mathrm{~mm} / \mathrm{s}$ 조 건에서는 QT6 샘플이 as-built 샘플에 비해 상대적으로 낮 은 마모량을 나타내었지만 $50 \mathrm{~N}-100 \mathrm{~mm} / \mathrm{s}$ 조건에서는 반 대로 as-built 샘플이 QT6에 비해 낮은 마모량을 보였는데, 이를 고려하면 그림 14의 상대재가 $\mathrm{ZrO}_{2}$ 일 때의 as-built 샘플의 0.75 정도의 높은 마찰계수는 샘플의 마모속도와는 관련 없이 나타나는 현상으로 생각된다. 이와 같은 현상의 
(a)

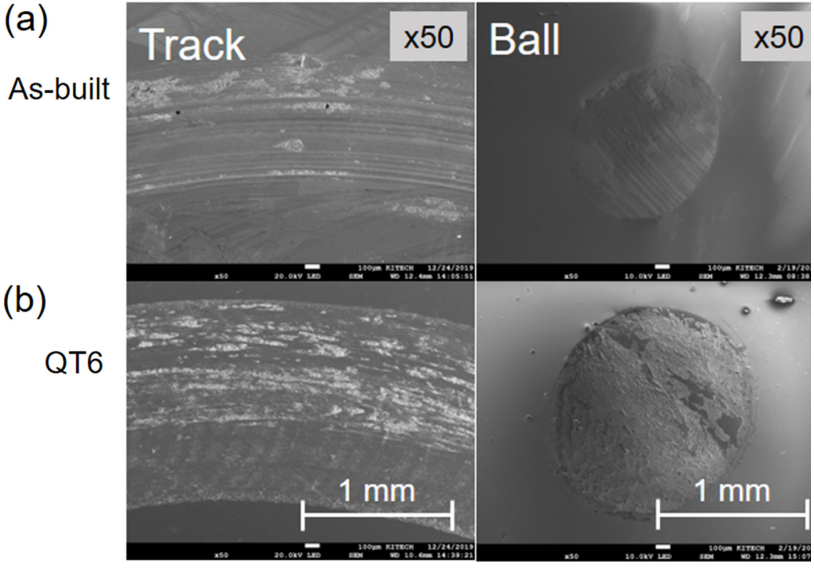

Fig. 15. SEM images showing wear scar morphologies of samples and $\mathrm{ZrO}_{2}$ balls for (a) as-built and (b) QT6, tested under wear load of $50 \mathrm{~N}$ and wear sliding speed of $100 \mathrm{~mm} / \mathrm{s}$.

원인은 그림 15 에 나타낸 상대재가 $\mathrm{ZrO}_{2}$ 일 때의 마모상 흔의 차이를 통해 설명할 수 있는데, 그림 15(a) 에 나타 낸 as-built 샘플과 $\mathrm{ZrO}_{2}$ ball의 마모상흔을 보면 ball의 마 모가 거의 일어나지 않고 마모시험 이후에도 ball의 표면 이 매끈한 것을 확인할 수 있는 반 면, 그림 $15(\mathrm{~b})$ 의 QT6 샘플의 경우 $\mathrm{ZrO}_{2}$ ball의 마모 역시 상당히 일어남을 알 수 있다. 이와 같은 차이는 HWS의 미세조직에 열처리 에 의해 형성된 높은 경도의 탄화물 때문으로 생각된다. 이를 고려해 보면, as-built와 달리 QT6 샘플에서는 $\mathrm{ZrO}_{2}$ ball 의 마모 역시 일정 부분 일어나기 때문에 ball에서 탈 락한 경도 높은 마모생성물이 마찰면에서 샘플과 ball 사이 에서 제 3 체에 의한 마모 ( $3^{\text {rd }}$ body wear) 를 일으키며 마찰 계수를 감소시키기 때문인 것으로 이해할 수 있다 [32].

본 논문에 제시된 실험 결과들을 종합해 보면, $\mathrm{DED}$ 로 적층 제조된 $\mathrm{HWS}$ 강의 마모특성은 열처리 유무와 상관 없 이 전반적으로 매우 뛰어난 것을 알 수 있으며, Hertzian 접촉응력 $1 \mathrm{GPa}$ 이상의 고하중 조건에서 고경도 소재인 베어링강과 $\mathrm{ZrO}_{2}$ 소재와의 마모에서 $500 \mathrm{~m}$ 의 총 미끌림 거리로 시험한 이후에 가장 마모가 극심한 조건에서도 샘 플의 마모량이 $25 \mu \mathrm{g}$ 미만의 아주 적은 양의 마모만이 일 어났다. 열처리를 하지 않은 as-built 상태에서는 그림 $13(\mathrm{c})$ 에 나타낸 것과 같이 상대재와 관계 없이 약 $15 \mu \mathrm{m}$ 미만의 아주 미미한 마모깊이 만큼만 마모되는 우수한 성 능을 나타내었다. HWS의 마모특성과의 상대적인 마모량 의 비교를 위해 기어부품 등 기계구조물에 광범위하게 쓰 이는 KS D3867 크롬 몰리브덴 합금강을 본 실험에서 사 용한 조건과 동일 조건으로 베어링 강 ball 을 상대재로 하여 마모시험 했을 때에는 극심한 마모손상으로 미끌림
거리를 $90 \mathrm{~m}$ 로 제한해서 시험했음에도 불구하고 $50 \mathrm{~N}-$ $100 \mathrm{~mm} / \mathrm{s}$ 조건에서 침탄처리 하지 않을 시 마모깊이 약55 $\mu \mathrm{m}$, 완전침탄처리 했을 경우에도 약 $13 \mu \mathrm{m}$ 정도의 마모손 상이 일어나는 것을 확인할 수 있었다. 동일한 조건으로 asbuilt 상태의 HWS를 미끌림 거리 $90 \mathrm{~m}$ 로 제한하여 시험했 을 때의 마모깊이는 $5 \mu \mathrm{m}$ 미만으로, as-built 상태의 DED 적층된 HWS 의 마모특성이 기어부품 등에 쓰이는 완전침 탄처리된 구조강에 비해서도 매우 우수함을 알 수 있었다.

선행연구[12]에서는 탄화텅스텐을 상대재로 하여 높은 하 중과 빠른 미끌림 속도 조건 (Hertzian 접촉응력 1519 $\mathrm{MPa}$, 미끌림 속도 $130 \mathrm{~mm} / \mathrm{s}$ ) 에서 짧은 미끌림 거리 $(78.5 \mathrm{~m})$ 를 사용하여 열처리 전후의 $\mathrm{HWS}$ 의 마모특성을 비 교하였는데, 이 경우에는 담금질 및 뜨임처리한 HWS가 asbuilt에 비해 상대적으로 더욱 우수한 마모특성을 보였다. 하 지만 본 논문에서 더욱 자세히 분석한 결과들을 놓고 보면, 담금질 및 뜨임처리한 $\mathrm{HWS}$ 는 마모시 주요 손상기구가 산 화피막의 형성 및 이의 박리로 이루어 지기 때문에 as-built 상태의 HWS 가 오히려 열처리를 한 경우에 비해 장기적인 재료의 내구성 관점에서 더욱 우수한 것으로 나타났으며 이 러한 경향은 상대재가 금속인 경우와 세라믹인 경우 모두 동일하게 나타났다. 이는 동소재를 소결이나 cladding 처리 할 경우에는 나타나지 않는 현상으로, 아마도 $\mathrm{DED}$ 의 국부 적인 입열과 빠른 냉각에 의한 미세한 조직에 따른 결과인 것으로 생각된다. 따라서 기어부품 등 재료의 장기적인 마 모내구성을 요하는 적용처에 $\mathrm{DED}$ 로 $\mathrm{HWS}$ 를 국부강화 혹 은 보수할 경우 담금질 및 뜨임처리를 통한 탄화물의 분산 은 마모상대재와 상관 없이 지양해야 할 것으로 보인다.

\section{4. 결 론}

본 연구에서는 $\mathrm{DED}$ 공정으로 적층된 $\mathrm{Fe}-8 \mathrm{Cr}-3 \mathrm{~V}-2 \mathrm{Mo}-2 \mathrm{~W}$ 합금의 내마모 특성을 다양한 열처리 조건에서 2 가지 서 로 다른 상대재를 사용하여 상세히 분석하였다. 마모특성 에 미치는 마모하중과 미끌림 속도의 영향 역시 실험을 통 해 분석하여 다음과 같은 결론을 얻을 수 있었다.

As-built 상태의 Fe-8Cr-3V-2Mo-2W 합금의 마모특성은 우수하였고, 마모하중과 미끌림속도가 빨라짐에 따라 마모 율이 선형적으로 증가하였다.

상대재가 베어링강인 경우, $\mathrm{Fe}-8 \mathrm{Cr}-3 \mathrm{~V}-2 \mathrm{Mo}-2 \mathrm{~W}$ 합금의 마모특성은 뜨임 열처리와 상관없이 열처리 공정을 거친 경우가 as-built상태보다 상대적으로 높은 마모속도를 보였 다. 이는 본 합금이 as-built 상태에서는 순수 절삭 마모기 구로만 마모가 일어나는 반면, 열처리를 거칠 경우에는 산 
화피막의 형성 및 박리에 의한 추가적인 마모기구가 활성 화 됨에 따른 것으로 보인다.

상대재가 $\mathrm{ZrO}_{2}$ 인 경우, as-built 의 마모속도가 비교적 높 은 반면 열처리를 거친 합금의 경우 베어링강이 상대재인 경우가 마모속도가 높았다. 이는 상대재를 $\mathrm{ZrO}_{2}$ 로 사용한 경우 합금의 열처리를 했을 경우에만 $\mathrm{ZrO}_{2}$ 이 함께 마모되 는 현상이 발생하기 때문으로 보이며, 이는 열처리에 의해 생성된 탄화물에 의한 $\mathrm{ZrO}_{2}$ 의 마모에 의한 것으로 사료된 다. $\mathrm{ZrO}_{2}$ 이 함께 마모되는 조건에서는 $\mathrm{ZrO}_{2}$ 파편에 의한 third body 마모기구가 활성화 하는 현상도 관찰되었다.

As-built 상태에서 $\mathrm{Fe}-8 \mathrm{Cr}-3 \mathrm{~V}-2 \mathrm{Mo}-2 \mathrm{~W}$ 합금은 추가적인 열처리 없이도 담금질 및 뜨임처리한 경우보다 비슷하거나 조건에 따라서는 더욱 우수한 마모거동을 보이므로 향후 기계구조에 적용할 시 열처리 없이도 사용할 수 있는 장점 을 보일 것으로 기대된다.

\section{감사의 글}

본 연구는 산업통상자원부와 한국산업기술진흥원이 지원 하는 국제공동기술개발사업 (No. G02P03040000701) 및 2019년도 교육과학기술부의 재원으로 한국연구재단의 지원 (No. 2019R1F1A1058837) 을 받아 수행되었으며 이에 감 사드립니다.

\section{REFERENCES}

1. J. H. Jang, B. D. Joo, C. J. Van Tyne, and Y. H. Moon, Met. Mater. Int. 19, 497 (2013).

2. T. W. Hwang, Y. Y. Woo, S. W. Han, and Y. H. Moon, Opt. Laser Technol. 105, 80 (2018).

3. B. D. Joo, J. H. Jang, J. H. Lee, Y. M. Son, and Y. H. Moon, T. Nonferr. Metal. Soc. 19, 921 (2009).

4. M. Fujishima, Y. Oda, R. Ashida, K. Takezawa, and M. Kondo, CIRP J. Manuf. Sci. Tec. 19, 200 (2017).

5. J. Y. Lee, J. An, and C. K. Chua, Appl. Mater. Today 7, 120 (2017).

6. T. D. Ngo, A. Kashani, G. Imbalzano, K. T. Q. Nguyen, and D. Hui, Compos. Part B Eng. 143, 172 (2018).

7. J. Leunda, V. G. Navas, C. Soriano, and C. Sanz, Phys. Procedia 39, 392 (2012).

8. J. Leunda, V. García Navas, C. Soriano, and C. Sanz, Surf. Coat. Tech. 259, 570 (2014).

9. G. Y. Baek, G. Y. Shin, K. Y. Lee, and D. S. Shim, Korean J. Met. Mater. 56, 430 (2018).
10. S. Jelvani, R. Shoja Razavi, M. Barekat, and M. Dehnavi, Met. Mater. Int. 26, 668 (2020).

11. E. Martinez González, Ph.D. Thesis, Universitat Politècnica de Catalunya, Barcelona (2014).

12. G. Y. Baek, G. Y. Shin, K. Y. Lee, and D. S. Shim, Metals. 9 , 282 (2019).

13. E. S. Lee, J. W. Park, and Y. H. Moon, Int. J. Adv. Manuf. Tech. 20, 720 (2002).

14. J. D. Majumdar, A. Pinkerton, Z. Liu, I. Manna, and L. Li, Appl. Surf. Sci. 247, 373 (2005).

15. M. Ziętala, T. Durejko, M. Polański, I. Kunce, T. Płociński, W. Zieliński, M. Łazińska, W. Stępniowski, T. Czujko, K. J. Kurzydłowski, and Z. Bojar, Mater. Sci. Eng. A 677, 1 (2016).

16. N. Ur Rahman, M. B. de Rooij, D. T. A. Matthews, G. Walmag, M. Sinnaeve, and G. R. B. E. Römer, Tribol. Int. 130, 52 (2019).

17. J. Sander, J. Hufenbach, L. Giebeler, M. Bleckmann, J. Eckert, and U. Kühn, Scr. Mater. 126, 41 (2017).

18. K. C. Bae, K. S. Ha, Y. H. Kim, J. J. Oak, W. Lee, and Y. H. Park, Int. J. Adv. Manuf. Tech. 108, 2385 (2020).

19. N. Hashemi, A. Mertens, H. M. Montrieux, J. T. Tchuindjang, O. Dedry, R. Carrus, and J. Lecomte-Beckers, Surf. Coat. Tech. 315, 519 (2017).

20. Y. Lee, M. Nordin, S. S. Babu, and D. F. Farson, Metall. Mater. Trans. B 45, 1520 (2014).

21. S. Wei, J. Zhu, and L. Xu, Tribol. Int. 39, 641 (2006).

22. K. Ha, T. Kim, G. Yun, J. Bae, D. Shim, Y. Hoon, and W. Lee, Addit. Manuf. 34, 101245 (2020).

23. D. Kim, T. Kim, K. Ha, J.-J. Oak, J. B. Jeon, Y. Park, and W. Lee, Metals 10, 410 (2020).

24. G. A. Tomlinson, Phil. Mag. Ser. 7, 905 (1929).

25. C. X. Li, J. Xia, and H. Dong, Wear 261, 693 (2006).

26. V. Krasmik and J. Schlattmann, Tribol. Online 11, 130 (2016).

27. C. Morillo, Y. Sawae, and T. Murakami, Tribol. Online 4, 127 (2009).

28. C. Kanchanomai, B. Saengwichian, and A. Manonukul, Wear 267, 1665 (2009).

29. A. Bahrami, S. H. M. Anijdan, M. A. Golozar, M. Shamanian, and N. Varahram, Wear 258, 846 (2005).

30. D. S. Shim, G. Y. Baek, S. B. Lee, J. H. Yu, Y. S. Choi, and S. H. Park, Surf. Coat. Tech. 328, 219 (2017).

31. A. Mulone, A. Nicolenco, N. Imaz, J. Fornell, J. Sort, and U. Klement, Wear 448-449, 203232 (2020).

32. O. Barrau, C. Boher, R. Gras, and F. Rezai-Aria, Wear 263, 160 (2007). 